\title{
Structural and Physical Properties of a Necrosis-Inducing Toxin from Pyrenophora tritici-repentis
}

\author{
Hui-Fen Zhang, Leonard J. Francl, James G. Jordahl, and Steven W. Meinhardt
}

First and fourth authors: Department of Biochemistry, 166 Loftsgard Hall; and second and third authors: Department of Plant Pathology, 306 Walster Hall, North Dakota State University, Fargo 58105.

Accepted for publication 5 November 1996.

\begin{abstract}
Zhang, H.-F., Francl, L. J., Jordahl, J. G., and Meinhardt, S. W. 1997. Structural and physical properties of a necrosis-inducing toxin from $P y$ renophora tritici-repentis. Phytopathology 87:154-160.

Cultivar-specific toxic metabolites of Pyrenophora tritici-repentis are involved in the appearance of necrotic and chlorotic foliar lesions characteristic of tan spot. A P. tritici-repentis necrosis-inducing toxin, Ptr necrosis toxin, was purified from isolate $86-124$, sequenced by gas-phase amino acid microsequencing, and characterized by circular dichroism (CD) spectroscopy and isoelectric focusing. The purified protein had a

and $25 \%$ other structures. The Ptr necrosis toxin from isolate $86-124$ has an isoelectric point near $\mathrm{pH} 10$. Using overlapping proteolytic fragments obtained from the toxin, a sequence of 101 continuous amino acids was obtained, but the amino terminus was blocked and 9 to 16 amino acids could not be sequenced. Secondary structure prediction based on the amino acid sequence indicated a $\beta$-sheet protein with little $\alpha$-helix, which is in agreement with the structure determined by CD spectroscopy. Sequence analysis indicated the presence of a possible membrane adhesion site and several possible phosphorylation sites that may be involved in phytotoxicity.
\end{abstract} similar amino acid composition and molecular weight as previously reported. Analysis of the CD spectrum from 178 to $250 \mathrm{~nm}$ indicated a protein consisting of $13 \% \alpha$-helix, 36\% antiparallel $\beta$-sheet, $25 \%$ turns,
Additional keywords: protein isolation, Triticum aestivum, wheat.
Tan spot or yellow spot of wheat (Triticum spp.), caused by $P y$ renophora tritici-repentis (Died.) Drechs., is an important foliar disease worldwide. Major areas of disease occurrence are the intensive wheat production areas of Australia, South America, and North America. Yield losses of 3 to $50 \%$ have been reported in these locations $(21,33,37)$. Tan spot was ranked recently as the most serious of the economically important foliar wheat diseases in North Dakota (32). The name of the disease comes from characteristic light brown necrotic lesions often surrounded by chlorotic halos.

Tan spot is currently managed by crop rotation, plowing under wheat debris, and fungicides, because many of the widely grown wheat cultivars are susceptible $(21,32,34)$. Genetic resistance, however, is the most environmentally safe and economical means of managing tan spot. Reports of inheritance of tan spot resistance in Triticum species have included both qualitative $(29,30,45)$ and quantitative gene action $(5,15,35)$. A single recessive gene conferred resistance to the necrotic reaction caused by a proteinaceous toxin produced by many pathogenic isolates of $P$. triticirepentis $(28,29)$. The single-gene model for reaction to the necrosis-inducing protein was independently confirmed (14), and flanking DNA markers have been located on chromosome 5BL (17). A spreading chlorosis symptom is caused by at least one other fungal metabolite and is under separate genetic control (16,27-29).

The necrosis-inducing protein was purified and partially characterized by two independent groups using essentially the same procedure $(2,47)$. Recently, a similar toxin has been purified by another method (49). All groups isolated a water-soluble protein

Corresponding author: S. Meinhardt

E-mail address: smeinhar@badlands.nodak.edu

Publication no. P-1997-0102-01R

(C) 1997 The American Phytopathological Society with a molecular mass between 13,000 and 14,000 Da. Reduction of the protein by dithiothreitol resulted in loss of biological activity (2). Somewhat disparate results were observed by the different groups regarding thermal inactivation and the specific activity of the toxin $(2,47,49)$. Tuori et al. (49) and Tomás et al. (47) claimed to have a thermally stable protein, still active after $10 \mathrm{~min}$ at 80 and $100^{\circ} \mathrm{C}$, while the protein isolated by Ballance et al. (2) was only moderately stable, active after $15 \mathrm{~min}$ at $70^{\circ} \mathrm{C}$, but inactive after $30 \mathrm{~min}$ at $70^{\circ} \mathrm{C}$. Although the amino acid content and molecular mass have been determined by these research groups, there is no information available on the primary or secondary structure of the toxin or any of its other physical properties.

A method is described here for isolating necrosis toxin that is similar to that used by Tuori et al. (49) and briefly reported by our research group (31). This method allows the purification of large quantities of toxin for experimentation. We have also characterized the toxin by sodium dodecyl sulfate (SDS) gel electrophoresis, nondenaturing isoelectric focusing, and circular dichroism (CD) spectroscopy. A major portion of the toxin was sequenced by gas-phase amino acid sequencing, and an extinction coefficient for both denatured and native toxin was determined. Based on the sequence data, a secondary structure for the toxin is predicted and is consistent with that determined by CD spectroscopy.

\section{MATERIALS AND METHODS}

Culture conditions. The isolate $86-124$ of $P$. tritici-repentis was obtained from L. Lamari (University of Manitoba, Winnipeg, Canada) and subcultured on V8-potato dextrose agar (PDA) (150 $\mathrm{ml}$ of V8 juice, $10 \mathrm{~g}$ of PDA, $3 \mathrm{~g}$ of $\mathrm{CaCO}_{3}, 10 \mathrm{~g}$ of agar, and 850 $\mathrm{ml}$ of distilled water). This isolate was characterized as a producer of a necrosis toxin and nonproducer of chlorosis toxin (28). Cultures were stored at $-80^{\circ} \mathrm{C}$ as dried mycelial plugs. These dried mycelial plugs were used to produce additional dried plugs that were stored at $-20^{\circ} \mathrm{C}$ for the duration of the experiment. 
Inoculum was produced by placing two dried mycelial plugs 3 $\mathrm{cm}$ apart on petri plates containing V8-PDA medium. Plates were incubated for 5 to 6 days at $20^{\circ} \mathrm{C}$ under continuous darkness. Ten 0.5 -cm-diameter plugs of mycelia were transferred to $50 \mathrm{ml}$ of potato dextrose broth and cultured on a wrist-action shaker at room temperature for 4 to 6 days. Cultures were blended under sterile conditions and transferred with a syringe in 1-ml aliquots to $50 \mathrm{ml}$ of liquid Fries medium (12). Cultures were held at 20 to $22^{\circ} \mathrm{C}$ in darkness for 28 days to produce necrosis toxin as previously described (28).

Extraction of necrosis toxin began with passage through a Whatman No. 1 filter (Whatman International, Ltd., Maidstone, England) under vacuum. Crude extract was checked for activity by infusion with about $25 \mu \mathrm{l}$ of filtrate into the second or third leaf of ND495 (sensitive) and 'Erik' (insensitive). The effect of the filtrate was assayed using the scoring system proposed by Tomás and Bockus (46).

Ptr necrosis toxin purification. Crude extract, 200 to 2,000 $\mathrm{ml}$, was centrifuged for $20 \mathrm{~min}$ at $35,000 \times g$. The supernatant was filtered through a $0.45-\mu \mathrm{m}$ Whatman nylon filter (Whatman International, Ltd.), placed in dialysis tubing $(3,500$ molecular weight cut-off), and dialyzed overnight against $2 \times 5$ volumes of $20 \mathrm{mM}$ sodium acetate buffer, $\mathrm{pH}$ 4.8. The dialyzed extract was loaded onto a fresh 10-ml S-Sepharose Fast Flow column (Pharmacia Biotechnology Inc., Uppsala, Sweden), $1.6 \times 5 \mathrm{~cm}$, previously equilibrated with $20 \mathrm{mM}$ sodium acetate. After loading, the column was washed with four column volumes of buffer at a flow rate of $1 \mathrm{ml} / \mathrm{min}$. The sample was eluted with a linear gradient from 0 to $300 \mathrm{mM} \mathrm{NaCl}$ over four column volumes, and the elution profile was measured spectrophotometrically at $280 \mathrm{~nm}$. Samples from 80 to $230 \mathrm{mM} \mathrm{NaCl}$ were combined and concentrated approximately 10 -fold by vacuum distillation at room temperature. The concentrated sample was chromatographed on a HiLoad 16/60 Superdex-30 gel filtration column (Pharmacia Biotechnology Inc.) at a flow rate of $0.5 \mathrm{ml} / \mathrm{min}$. A peak centered near $14,000 \mathrm{Da}$ was collected. In most preparations, the toxin is $80 \%$ pure at this step based on a comparison of peak areas observed in reversed phase high pressure liquid chromatography (HPLC). The sample was desalted by concentration to a volume of $2 \mathrm{ml}$ using the Amicon Centriprep-3 ultra-filtration system (Amicon, Beverly, MA) and then diluted fivefold with $20 \mathrm{mM}$ sodium acetate, $\mathrm{pH}$ 4.8. The desalted sample was loaded onto a HPLC sulfo-propyl ion exchange column (Beckman Sperogel TSK SP-5PW, $7.5 \mathrm{~mm}$ $\times 7.5 \mathrm{~cm}$; Beckman Instruments, Inc., San Ramon, CA) and eluted at a flow rate of $1 \mathrm{ml} / \mathrm{min}$ with a linear gradient from 0 to $400 \mathrm{mM}$ $\mathrm{NaCl}$ over $40 \mathrm{~min}$.

Electrophoresis. Denaturing SDS-polyacrylamide gel electrophoresis was carried out in a Mini Protein II vertical gel electrophoresis system (Bio-Rad Laboratories, Hercules, CA) using a 16\%:3\% gel (the first number denotes the total acrylamide concentration, i.e., both monomers, and the second number indicates the concentration of crosslinker) and the buffer system of Schägger and von Jagow (43). Samples of toxin and molecular weight standards, typically 5 to $10 \mu \mathrm{g}$ of protein, were prepared by a fivefold dilution in sample buffer (5\% 2- $\beta$-mecaptoethanol, $2 \%$ SDS, $63 \mathrm{mM}$ Tris-HCl [pH 6.8], 10\% glycerol, and $0.005 \%$ bromophenol blue) and heated for $5 \mathrm{~min}$ at $100^{\circ} \mathrm{C}$. Molecular weight markers, MW-SDS-70L and MW-SDS-17S, were obtained from Sigma Chemical Co. (St. Louis). Samples were stained with either Coomassie brilliant blue (R-250) for $1 \mathrm{~h}$ and then destained or stained with the Bio-Rad Silver Stain Plus (Bio-Rad Laboratories).

Nondenaturing isoelectric focusing was performed with the Bio-Rad Mini Protein II system (Bio-Rad Laboratories). A 12-ml solution of $5 \%$ polyacrylamide $(24.25 \%$ acrylamide: $0.75 \%$ piperazine diacrylamide [Bio-Rad Laboratories]), 5\% glycerol, and 2\% ampholytes, Biolyte 3-10 (Pharmacia Biotechnology Inc.), was degassed and polymerization initiated by adding $20 \mu \mathrm{l}$ each of $10 \%$ ammonium persulfate and $N, N, N^{\prime}, N^{\prime}$-tetramethyleth- ylenediamine (TEMED). After polymerization, the anode buffer, $0.02 \mathrm{M}$ phosphoric acid, and cathode buffer, $0.04 \mathrm{M}$ sodium hydroxide, were added, and the sample wells were filled with overlay buffer $(0.87 \mathrm{ml}$ of water, $0.1 \mathrm{ml}$ of $50 \%$ glycerol, $15 \mu \mathrm{l}$ of Biolyte 5-7 (Bio-Rad Laboratories), $5 \mu$ of Biolyte 3-10 (Bio-Rad Laboratories), and $20 \mu \mathrm{l}$ of $1 \%$ bromophenol blue). Samples and standards (isoelectric focusing standards [Bio-Rad Laboratories]) were dissolved in an equal volume of $50 \%$ glycerol and layered under the overlay buffer. Samples were electrophoresed by stepped increases in voltage (100 V for $15 \mathrm{~min}, 200 \mathrm{~V}$ for $30 \mathrm{~min}$, $300 \mathrm{~V}$ for $45 \mathrm{~min}$, and $400 \mathrm{~V}$ for $30 \mathrm{~min}$ ). The outer buffer chamber was stirred with a magnetic stirrer throughout the electrophoresis to dissipate heat. After electrophoresis, the gels were carefully removed and fixed in a solution of $12 \%$ trichloroacetic acid, $4.5 \%$ sulfosalicylic acid, and $40 \%$ methanol for a period of 2 to $4 \mathrm{~h}$ with one change in the fixing solution. The gels were then washed for 2 to $8 \mathrm{~h}$ with water and stained with Coomassie brilliant blue R-250. The $\mathrm{pH}$ gradient was measured directly by slicing an unused portion of the gel in 3-mm sections and placing the sections in $1 \mathrm{ml}$ of water under vacuum for $2 \mathrm{~h}$.

In one experiment, an isoelectric focusing gel was run as described above with the toxin present in half the wells to check for biological activity. The gel was sliced in half vertically to separate the toxin-containing and toxin-free portions. These portions were then sliced horizontally in 3-mm strips and placed in water as described for measuring the $\mathrm{pH}$ gradient. The activity of each solution, sample and reference, was then bioassayed as described above.

Amino acid composition and sequencing. The amino acid composition was determined from two independent samples of $100 \mu \mathrm{g}$ using a Beckman System Gold amino acid analyzer (Beckman Instruments, Inc.) after acid hydrolysis of the protein. For amino acid sequencing, the necrosis toxin was cleaved by several methods. In each case, 100 to $150 \mu \mathrm{g}$ of protein was dialyzed against the appropriate buffer. Controls containing only the endoproteinase or chemical reagent were performed for each experiment. Endoproteinase aspartate-N (Boehringer Mannheim Corp., Indianapolis, IN) digests were performed with $1 \mu \mathrm{g}$ of enzyme in $50 \mathrm{mM}$ sodium phosphate buffer $(\mathrm{pH} 7.8)$ for 18 and 24 h. Endoproteinase glutamate-C digests (Boehringer Mannheim Biochemicals), $10 \mu \mathrm{g}$ of proteinase, were performed in $75 \mathrm{mM}$ ammonium bicarbonate buffer ( $\mathrm{pH} 7.8$ ) for $48 \mathrm{~h}$. Trypsin digestion was performed using $20 \mu \mathrm{l}$ of immobilized TPCK-trypsin (L-1tosylamide-2-phenylethyl chloromethyl ketone-treated trypsin) (Pierce, Rockford, IL) in $200 \mathrm{mM}$ ammonium bicarbonate buffer ( $\mathrm{pH} \mathrm{8.0)} \mathrm{for} 2$ and $24 \mathrm{~h}$. A third trypsin digest was performed in $100 \mathrm{mM}$ potassium phosphate buffer $(\mathrm{pH} \mathrm{7.8)}$ for $24 \mathrm{~min}$. The protein was digested for $18 \mathrm{~h}$ at room temperature with $3 \mu \mathrm{g}$ of chymotrypsin in $100 \mathrm{mM}$ Tris- $\mathrm{HCl}$ and $10 \mathrm{mM} \mathrm{CaCl}_{2}$ at $\mathrm{pH} 7.8$. The toxin was cleaved at the tryptophan residues by 2-(2'nitrophenylsulfenyl)-3-methyl-3'bromoindolenine (BNPS-skatole) according to the method described in Crimmins et al. (7), but with $75 \mu \mathrm{l}$ of toxin $(0.65 \mathrm{mg} / \mathrm{ml})$ in $20 \mathrm{mM}$ sodium acetate buffer added to an Eppendorf tube and dried. The protein was then resuspended in $10 \mu \mathrm{l}$ of water, cleaved as described by Crimmins et al. (7), and the fragments separated as described below. A total of 10 different digests were performed.

After each cleavage, peptide fragments were separated by reversed phase HPLC using a Beckman 126 HPLC with a Beckman $210 \mathrm{~A}$ injector (1-ml sample loop), and peptides were detected at $215 \mathrm{~nm}$ by a Beckman $166 \mathrm{UV}$ detector (Beckman Instruments, Inc.). Samples were eluted from a C-18 column (Rainin Microsorb-MV, $4.6 \mathrm{mM} \times 25 \mathrm{~cm}$; Rainin Instruments Co. Inc., Woburn, MA) with a linear gradient from 10 to $70 \%$ acetonitrile and $0.1 \%$ trifluoroacetic acid. In some cases, the gradient was modified to obtain better resolution near the uncleaved protein peak. Purified peptides were concentrated, spotted, and dried onto Porton peptide glass sample disks (Porton Instruments, Inc., Tarzana, CA). Peptides were sequenced by the Porton Instruments PI2090 gas-phase 
automated protein sequencer (Porton Instruments, Inc.). In sequencing fragments from the endoproteinase digests, each portion of the protein was sequenced at least twice. Cysteine residues were determined by the method described by Brune (4).

Protein assay and secondary structure. The protein concentration was measured with the micro bicinchoninic acid (BCA) assay (Pierce) using bovine serum albumin as the standard or using the extinction coefficient derived below and a molecular mass of 13,200 Da (49).

To determine the secondary structure of a protein from $\mathrm{CD}$ spectroscopy, the concentration must be determined within $5 \%$ for most analysis methods, but protein concentrations determined by typical assay methods (i.e., Bradford, Lowry, or BCA), often have errors approaching $20 \%$ depending on the purity of the protein sample and the similarity of the protein standard to the sample $(3,22)$. A more accurate method developed by Gill and von Hippel (20) is based on calculating the extinction coefficient from the
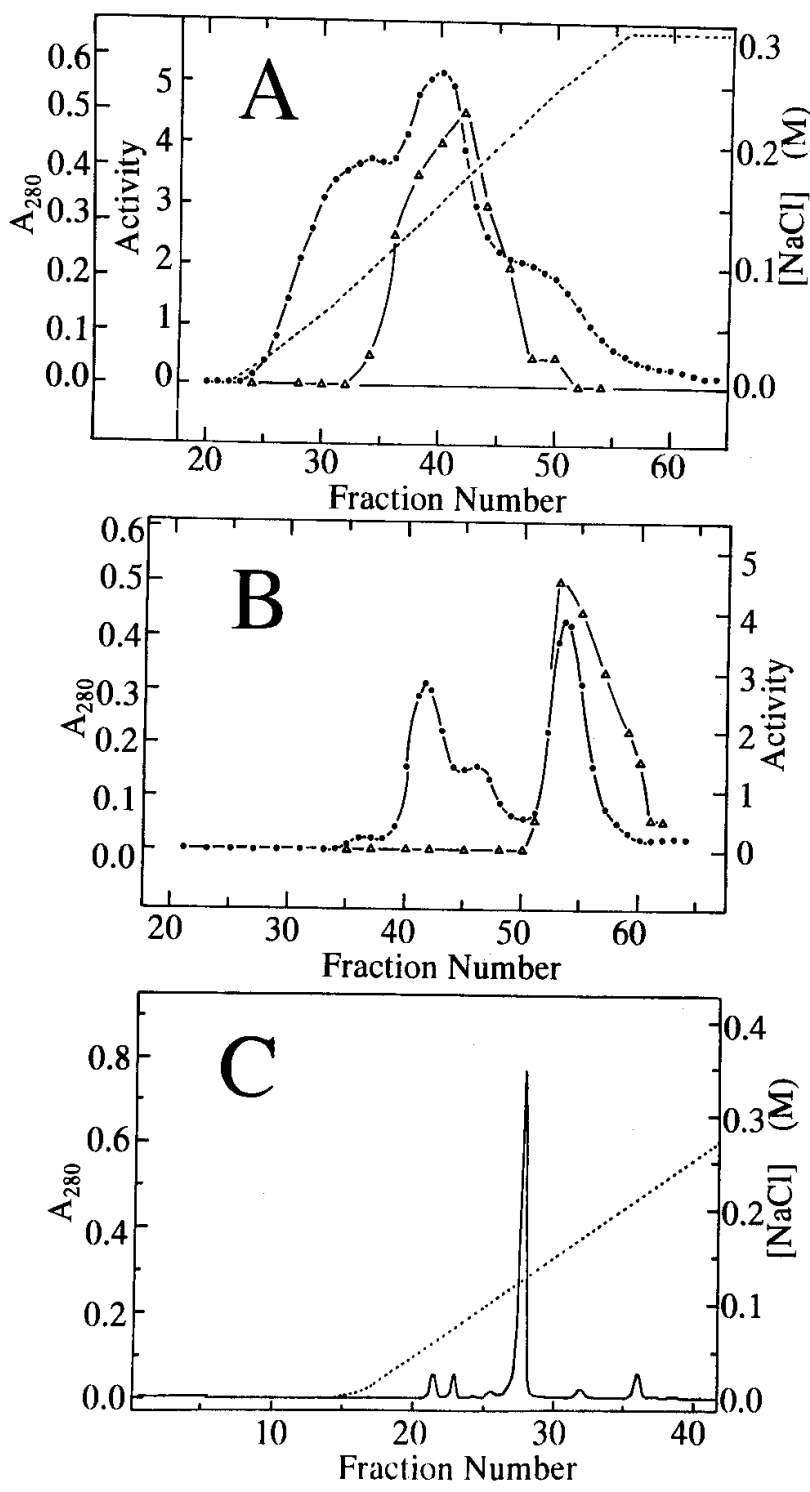

Fig. 1. Purification of the Ptr necrosis toxin from Pyrenophora tritici-repentis isolate 86-124. A, Chromatogram from low pressure S-Sepharose ion exchange chromatography showing the absorbance at $280 \mathrm{~nm}$, the sodium chloride gradient, and the activity assayed as described in the text. B, Superdex HR-30 gel filtration chromatography of the concentrated active fractions from panel A. Shown are the absorbance at $280 \mathrm{~nm}$ and the activity assay. $\mathbf{C}$, High pressure liquid chromatography sulfo-propyl cation exchange chromatography of the active samples from panel B. Shown are the absorbance at $280 \mathrm{~nm}$ and the sodium chloride gradient used to elute the protein. amino acid composition when the protein is denatured in $5 \mathrm{M}$ guanidine hydrochloride. The extinction coefficient of the necrosis toxin, $19.9 \mathrm{mM}^{-1} \mathrm{~cm}^{-1}$ at $280 \mathrm{~nm}$ (determined from 3-tryptophan and 2-tyrosine, obtained from our sequence, and 2-cysteine residues, Ballance et al. [2]) was calculated from the amino acid sequence according to Gill and von Hippel (20). The absorbance at $280 \mathrm{~nm}$ and this extinction coefficient was used to determine the toxin concentration in a stock solution. The same solution was then diluted into $50 \mathrm{mM}$ sodium phosphate, $150 \mathrm{mM}$ sodium chloride $(\mathrm{pH} 7.0)$, and the native extinction coefficient measured.

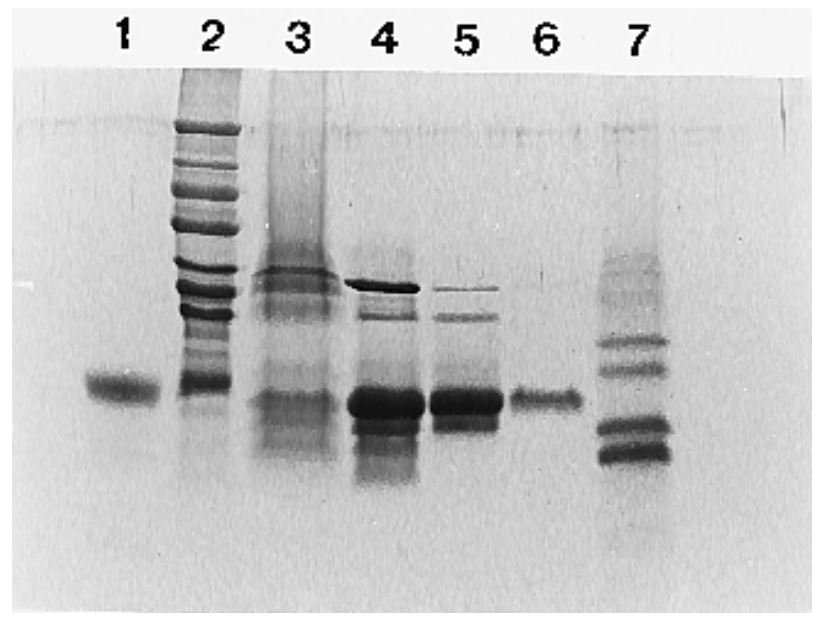

Fig. 2. Sodium dodecyl sulfate-polyacrylamide gel electrophoresis of fractions obtained during purification of the necrosis toxin. Samples were taken of each step during the purification and electrophoresed. The following samples were separated: lane 1, cytochrome c, 12,500 Da; lane 2, Sigma molecular weight standards MW-SDS-70L (bovine serum albumin, 66,000 Da; egg albumin, 45,000 Da; glyceraldehyde-3-phosphate dehydrogenase, 36,000 Da; bovine erythrocyte carbonic anhydrase, 29,000 Da; soybean trypsin inhibitor, 20,100; and bovine milk $\alpha$-lactalbumin, 14,200); lane 3, crude culture filtrate; lane 4, pooled active fractions from S-Sepharose column; lane 5, pooled active fractions from gel filtration column; lane 6, pure toxin obtained from high pressure liquid chromatography column; and lane 7, Sigma molecular weight standards MW-SDS-17S (myoglobin, 16,950 Da; myoglobin I + II, 14,440 Da; myoglobin I + III, 10,600 Da; myoglobin I, 8,160 Da; myoglobin II, 6,210 Da; glucagon, 3,460 Da; and myoglobin III, $2,510 \mathrm{Da}$ [not visible]).

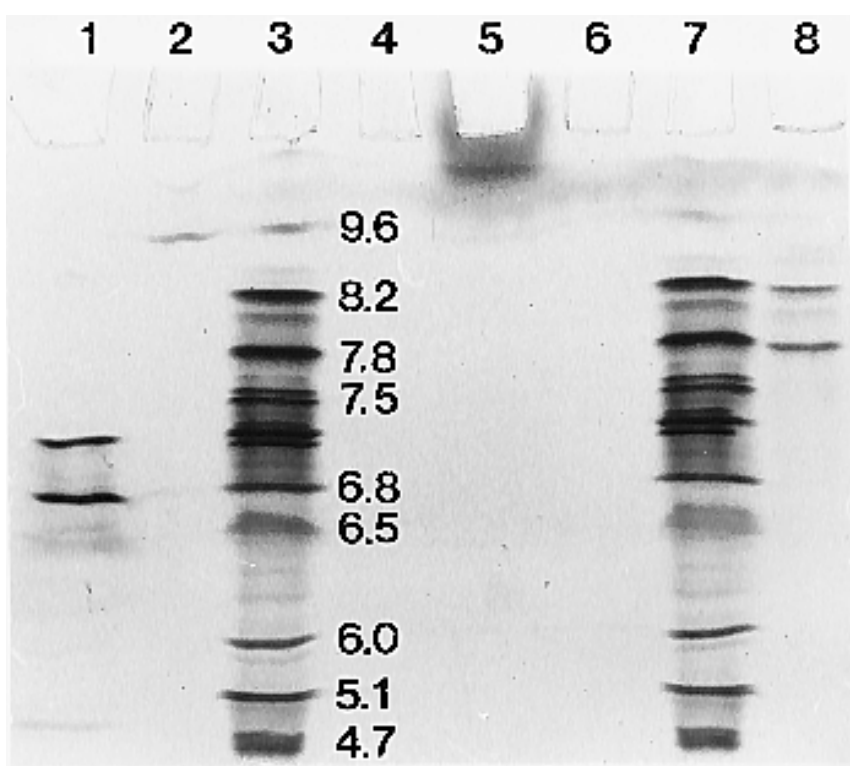

Fig. 3. The Ptr necrosis toxin and standards subjected to isoelectric focusing in a vertical slab gel system: lane 1, horse heart myoglobin, pI 6.8 and 7.2; lane 2, cytochrome c, pI 9.6; lane 3, Bio-Rad isoelectric focusing (IEF) standards; lane 4, empty; lane 5, necrosis toxin; lane 6, empty; lane 7, Bio-Rad IEF standards; and lane 8, lens culinaris lentil lectins, pI 8.8, 8.6, and 8.2. 
The CD spectrum of the toxin was measured using the JASCO J-700 CD spectrometer (Japan Spectroscopic Co., Ltd., Tokyo). The purified toxin, $1.25 \mathrm{mg} / \mathrm{ml}$ (determined from the extinction coefficient and a molecular weight of 13,200), in $20 \mathrm{mM}$ phosphate buffer ( $\mathrm{pH}$ 6.8) was placed in a cylindrical quartz cuvette, $0.1-\mathrm{mm}$ path length, and the CD spectrum measured from 178 to $260 \mathrm{~nm}$. The CD spectrum was analyzed for secondary structure composition by the program SELCON (44).

\section{RESULTS}

Isolation and electrophoresis. The toxin eluted from the first ion exchange column in a volume of $15 \mathrm{ml}$ (Fig. 1A), resulting in a 65-fold increase in concentration when starting with 1 liter of crude extract. Concentration of the active fractions to a volume of $2 \mathrm{ml}$ and separation by gel filtration (Fig. 1B) resulted in an active fraction, from 50 to $60 \mathrm{ml}$, that was typically 50 to $80 \%$ pure based on relative areas in the HPLC separation (Fig. 1C). The final separation by ion exchange using HPLC resulted in one major active peak that eluted between 110 and $140 \mathrm{mM} \mathrm{NaCl}$ (Fig. 1C). The purification procedure, shown by an SDS polyacrylamide gel of the pooled active fractions from each step in the purification, resulted in the isolation of a single protein band (Fig. 2). Reversed phase HPLC analysis of the purified Ptr necrosis toxin exhibited a single asymmetric peak, indicating a single protein in the preparation (data not shown). The molecular mass determined from this gel is near $12.4 \mathrm{kDa}$, which is lower than previously reported. It should be noted that the molecular weight standard $\alpha$ lactalbumin, lane 2 last band, has a molecular mass of $14.4 \mathrm{kDa}$ and is coincident with cytochrome $\mathrm{c}$, lane 1 , which has a molecular mass of $12.5 \mathrm{kDa}$. A plot of both standard sets, lanes 2 and 7 , indicated that $\alpha$-lactalbumin exhibits anomalous behavior in this electrophoresis system (data not shown). Silver stain was used to increase the staining sensitivity in order to look for contaminating proteins. Although the toxin did not stain with the silver stain

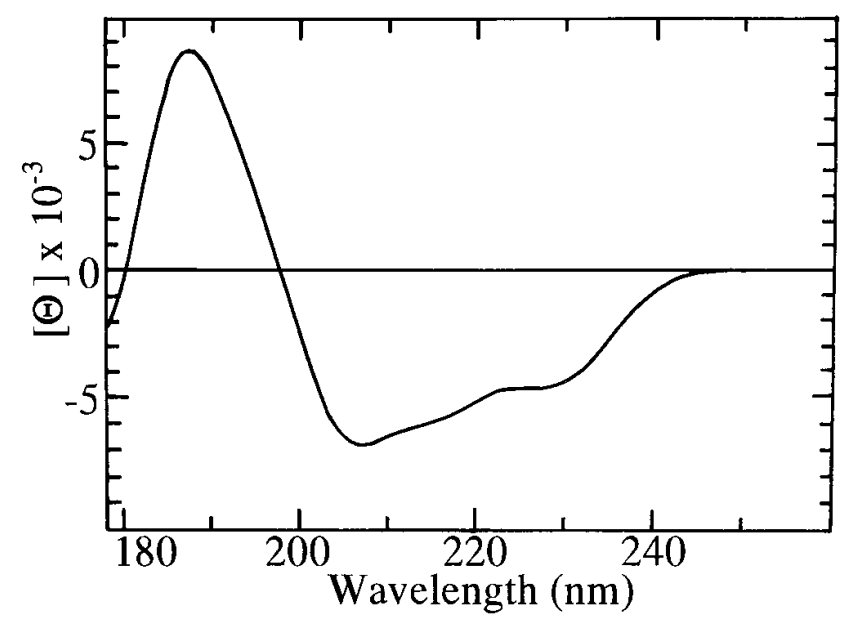

Fig. 4. Ptr necrosis toxin was suspended in $20 \mathrm{mM}$ sodium phosphate buffer, $\mathrm{pH} 6.8$, at a concentration of $1.29 \mathrm{mg} / \mathrm{ml}$, place in a $0.1-\mathrm{mm}$ path length circular cuvette and the circular dichroism spectrum measured. Shown is an average of 32 scans. $\Theta$ is in units of $\mathrm{M}^{-1} \mathrm{~cm}^{-1}$.

TABLE 1. Secondary structure predicted from circular dichroism spectrum for the Pyrenophora tritici-repentis necrosis toxin

\begin{tabular}{lccccc}
\hline \multirow{2}{*}{$\begin{array}{l}\text { Relative protein } \\
\text { concentration }^{\mathrm{a}}\end{array}$} & $\alpha$ & $\beta$ (antiparallel) & Turn & Other & Total \\
\cline { 2 - 5 } 0.95 & 0.08 & 0.41 & 0.24 & 0.26 & 0.99 \\
1.00 & 0.15 & 0.35 & 0.23 & 0.26 & 0.99 \\
1.05 & 0.15 & 0.32 & 0.28 & 0.24 & 0.99 \\
\hline
\end{tabular}

a Allowing for a $5 \%$ margin of error in measuring total protein concentration. used, no other proteins were detected even with excess amounts of toxin (data not shown).

A nondenaturing isoelectric focusing gel (Fig. 3) exhibited a single, very diffuse band with an isoelectric point near $\mathrm{pH} 10$. No other band was distinguishable at other $\mathrm{pH}$ values, suggesting a pure protein. The broadness of the band may be due to microheterogeneity in the protein. Bioassay of extracts from horizontally sliced gel sections indicated activity only in the section containing observable protein. Thus, the protein isolated by this purification procedure was a necrosis-producing phytotoxin.

Protein concentration and secondary structure. To obtain an accurate measurement of the protein concentration for use in CD spectroscopy, we used the amino acid composition and sequence information. An extinction coefficient of $19.9 \mathrm{mM}^{-1} \mathrm{~cm}^{-1}$ at 280 $\mathrm{nm}$ in the presence of $5 \mathrm{M}$ guanidine hydrochloride was calculated based on 2-tyrosine, 3-tryptophan, and 2-cysteine residues (20). Using the protein concentration determined in the presence of guanidine hydrochloride, the extinction coefficient of the native protein in phosphate buffer ( $\mathrm{pH} 7.0$ ) was $18 \mathrm{mM}^{-1} \mathrm{~cm}^{-1}$ at $280 \mathrm{~nm}$.

The secondary structure of the toxin was determined using CD spectroscopy from 178 to $260 \mathrm{~nm}$ (Fig. 4). This spectrum is similar to that observed for $\alpha$-chymotrypsin, which is mostly a $\beta$-sheet protein (48). Analysis of the $\mathrm{CD}$ spectrum using the program SELCON (44) for four components ( $\alpha, \beta$, turn, and other) indicated a mostly $\beta$-sheet protein with little $\alpha$-helix (Table 1 ). Further analysis for five components $(\alpha, \beta$-parallel, $\beta$-antiparallel, turn, and other) indicated that the $\beta$-sheet was completely antiparallel.

Amino acid composition and sequencing. The amino acid composition of our preparation can be compared with that obtained from other research groups (Table 2). Since we used the same isolate as Ballance et al. (2), we expected to obtain the same composition, and inspection of the table shows a close correlation between our results. Tuori et al. (49) and Tomás et al. (47) used closely related strains suggesting that the proteins would have a similar composition, but their results show differences in the mole percentages of serine and proline. The toxins produced by 86-124 and $\mathrm{Pt}-1 \mathrm{C}$ are similar in composition, but appear different in the mole percentages of proline, histidine, lysine, and arginine.

Figure 5 gives the sequence of a major portion of the toxin and indicates the overlapping fragments used to assemble the sequence. A total of 101 amino acids have been combined into a continuous sequence based on the sequence obtained from 50

TABLE 2. Amino acid composition (mole percentage) of isolated Pyrenophora tritici-repentis necrosis toxins

\begin{tabular}{lcccc}
\hline Amino acid & $\begin{array}{c}\text { Pt-1C-BFP } \\
\text { (ToxA) }^{\mathrm{a}}\end{array}$ & $\begin{array}{c}\text { Pt-1C } \\
\text { (Ptr toxin) }^{\mathrm{b}}\end{array}$ & $\begin{array}{c}86-124 \\
\left.\text { Ptr necrosis }^{\text {toxin) }}\right)^{\mathrm{c}}\end{array}$ & $\begin{array}{c}86-124 \\
\text { (Ptr necrosis }^{\text {toxin) }}{ }^{\mathrm{d}}\end{array}$ \\
\hline Asp/Asn & 17.7 & 18.7 & 17.2 & 18.5 \\
Thr & 7.7 & 7.0 & 7.9 & 7.3 \\
Ser & 6.3 & 10.7 & 7.3 & 6.0 \\
Glu/Gln & 7.9 & 9.2 & 8.1 & 8.8 \\
Pro & 5.3 & 8.4 & 3.0 & 3.7 \\
Gly & 11.0 & 10.5 & 11.2 & 11.5 \\
Ala & 3.2 & 4.3 & 3.1 & 3.4 \\
Val & 6.4 & 5.5 & 7.2 & 6.9 \\
Met & 1.6 & 0.7 & 1.3 & 1.4 \\
Ile & 9.8 & 4.3 & 10.3 & 10.5 \\
Leu & 6.9 & 4.9 & 7.0 & 7.0 \\
Tyr & 2.2 & 2.4 & 2.0 & 1.5 \\
Phe & 2.8 & 2.6 & 2.8 & 2.6 \\
His & 0.3 & 0.7 & 0.0 & 0.0 \\
Lys & 1.0 & 1.1 & 0.5 & 0.6 \\
Arg & 9.7 & 9.2 & 11.0 & 10.3 \\
\hline
\end{tabular}

a Data obtained from Tuori et al. (49).

b Data obtained from Tomás et al.(46).

c Data obtained from Ballance et al. (2).

${ }^{\mathrm{d}}$ Data reported here from two separate determinations. 


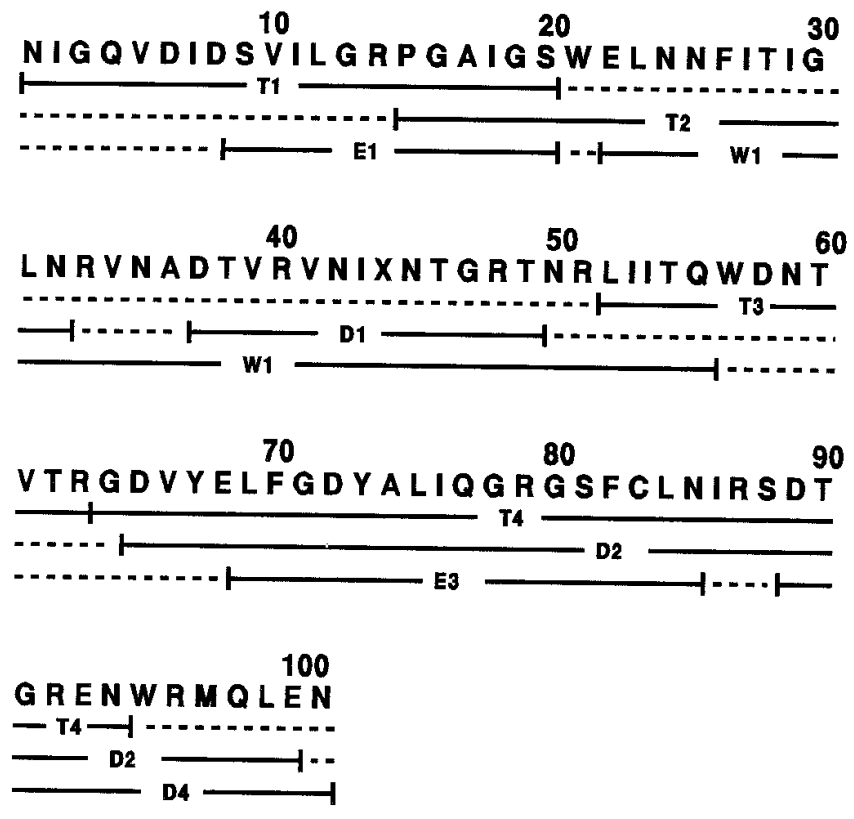

Fig. 5. The partial Ptr necrosis toxin sequence was obtained by gas-phase amino acid sequencing of proteolytic fragments separated by reversed phase high pressure liquid chromatography. The following reagents were used: Trypsin (T), endoproteinase Glu-C (E), endoproteinase Asp-N (D), and 2-(2'nitrophenylsulfenyl)-3-methyl-3'bromoindolenine (BNPS-skatole) (W). The symbol $\mathrm{X}$ represents either an arginine or aspartate residue.

different fragments generated by the digests. Assuming a molecular mass between 12.5 and $13.2 \mathrm{kDa}(49)$, a total of 9 to 16 amino acids are left to be sequenced. This should include a second cysteine residue based on the sensitivity of the protein to reduction by dithiothreitol (2). Since the N-terminal is blocked, it will be difficult to obtain these residues by direct amino acid sequencing. It appears that obtaining the complete amino acid sequence will require the cloning and sequencing of the cDNA.

Prediction of the secondary structure from the amino acid sequence by the methods of Chou and Fasman (6) as programmed by Deleage and Roux, and Deleage et al. (DR) $(6,8-11)$ and the PHD algorithm (38-41) is shown in Figure 6. All three methods predicted a mostly $\beta$-sheet structure with an $\alpha$-helix near the $\mathrm{C}$ terminal end. In two of the three prediction methods, PHD and DR, a short helical region was also predicted near residue 67. These predictions were consistent with the $\mathrm{CD}$ analysis of the toxin, suggesting up to $40 \% \beta$-sheet, but only 8 to $15 \% \alpha$-helix.

\section{DISCUSSION}

The purity of the toxin preparation obtained by our method was confirmed by SDS gel electrophoresis, reversed phase HPLC analysis, and isoelectric focusing. No proteins or biologically active components other than the native necrosis protein induced necrosis after isoelectric focusing. The toxin had an extremely basic $\mathrm{pI}$ in the native state and this result, and a small degree of heterogeneity in the protein structure, led to a diffuse band on the isoelectric focusing gel. The toxin was not stained by silver stain methods, although it was easily stained with Coomassie brilliant blue.

Purification of large quantities of toxin used for physical and biochemical analysis, genetic research, and wheat breeding requires an efficient method of concentrating the toxin from crude extract. Production of pure toxin by our method could easily be increased by increasing the column diameter for rapid loading of large quantities of crude extract. Our method has an advantage over that reported by Tuori et al. (49) in that colored material is removed early in the purification process. In addition, the elution from the first ion exchange column and the gel filtration separa- tion may be performed within a single day, allowing the rapid production of partially purified toxin.

Comparison of the amino acid composition among the toxins from three fungal isolates indicates several amino acid differences (Table 2). Most differences occurred in the positively charged amino acids and may represent somewhat conservative amino acid replacements, because toxicity was not significantly affected. Variation in composition suggests that a pool of toxin variants exists in the fungal population, and these variants (or induced mutants) would be useful for determining the amino acid residues important for toxin function.

Although we did not obtain the complete amino acid sequence, our results demonstrate that, so far, there are no modified amino acids in the toxin. This is an important step in the characterization of the toxin and in determining the mechanism of the toxin. Unusual or modified amino acids have been found in some peptide toxins $(23,25,26,50)$. Therefore, the results here eliminate, for the most part, unusual interactions between the toxin and its site of action. It should be relatively simple to use this amino acid sequence to confirm the toxin gene and, thus, obtain the complete amino acid and DNA sequences.

Analysis of CD spectra and primary sequence data indicated a mostly $\beta$-sheet protein. The number of $\beta$-strands predicted suggests that the toxin may form two overlapping $\beta$-sheets. Protein and DNA data bases were searched for proteins with similar sequences, but no significant matches were found, suggesting a unique biological function for this necrosis toxin. The comparison of the amino acid sequence with sequences of known function through PROSITE $(1,18,19)$ resulted in two interesting observations. First, the threonine residues at positions 38, 46, 49, and 90 are in sequences typical for phosphorylation by phosphokinase $\mathrm{C}$ (51). In addition, the threonine residues at positions 55, 62, and 90 are also within sequences typical for casein kinase II phosphorylation $(24,36)$. Although none of these amino acids were phosphorylated in the isolated protein, all of the possible phosphorylation sites except for threonine 91 are closely grouped and may be of importance to the mode of action if the protein is taken up by the host. Second, the tripeptide Arg-Gly-Asp at position 64 to 66, which was predicted as a turn region, has been found in a large number of proteins including collagens, fibrinogen, snake disintegrins, and slime mold discoidins $(13,42)$. In each case, this tripeptide was involved in the adhesion of the protein to the plasma membrane, and it may play a similar role in the necrosis toxin. Further study of protein regulation, structure, specific activity, and mode of action will clarify the role of the Ptr necrosis toxin in the Triticum-P. tritici-repentis pathosystem.

\section{ACKNOWLEDGMENTS}

We thank L. Lamari, University of Manitoba, Winnipeg, Canada, for supplying isolate 86-124 of Pyrenophora tritici-repentis. This research was supported, in part, by USDA-NRICGP seed grant 930-4121.

\section{LITERATURE CITED}

1. Bairoch, A. 1993. The PROSITE dictionary of sites and patterns in proteins, its current status. Nucleic Acids Res. 21:3097-3103.

2. Ballance, G. M., Lamari, L., and Bernier, C. C. 1989. Purification and characterization of a host selective necrosis toxin from Pyrenophora tritici-repentis. Physiol. Mol. Plant Pathol. 35:203-213.

3. Brooks, S. P. J., Lampi, B. J., Sarwar, G., and Botting, H. G. 1995. A comparison of methods for determining total body protein. Anal. Biochem. 266:26-30.

4. Brune, D. C. 1992. Alkylation of cysteine with acrylamide for protein sequence analysis. Anal. Biochem. 207:285-290.

5. Cantrell, R. G., Elias, E., and Hosford, R. M., Jr. 1985. The inheritance of resistance to tan spot in durum wheat. Agron. Abstr. 77:50.

6. Chou, P. Y., and Fasman, G. D. 1978. Prediction of the secondary structure of proteins from the amino acid sequence. Adv. Enzymol. Relat. Areas Mol. Biol. 47:45-148. 
7. Crimmins, D. L., McCourt, D. W., Thoma, R. S., Scott, M. G., Macke, K., and Schwartz, B. D. 1990. In situ chemical cleavage of proteins immobilized to glass-fiber and polyvinylidenedifluoride membranes: Cleavage at tryptophan residues with 2-(2'-nitrophenylsulfenyl)-3methyl-3'-bromoindolenine to obtain internal amino acid sequence. Anal. Biochem. 187:27-38.

8. Deleage, G., Clerc, F. F., and Roux, B. 1989. Antheprot: IBM-PC and Apple Macintosh versions. Comput. Appl. Biosci. 5:159-160.

9. Deleage, G., Clerc, F. F., Roux, B., and Gautheron, D. C. 1988. ANTHEPROT: A package for protein sequence analysis using a microcomputer. Comput. Appl. Biosci. 4:351-356.

10. Deleage, G., and Roux, B. 1987. An algorithm for protein secondary structure prediction based on class predictions. Protein Eng. 1:289-294.

11. Deleage, G., Tinland, B., and Roux, B. 1987. A computerized version of the Chou and Fasman method for predicting the secondary structure of proteins. Anal. Biochem. 163:292-297.

12. Dhinga, O. D., and Sinclair, J. B. 1985. Basic Plant Pathology Methods. CRC Press, Boca Raton, FL.

13. d'Souza, S. E., Ginsberg, M. H., and Plow, E. F. 1991. Arginyl-glycylaspartic acid (RGD): A cell adhesion motif. Trends Biochem. Sci. 16:246-250.

14. Duguid, S. D., and Brûle-Babél, A. L. 1992. The inheritance of resistance to necrosis-inducing pathotypes of Pyrenophora tritici-repentis. Pages 16-19 in: Advances in Tan Spot Research: Proceedings of the Second International Tan Spot Workshop. L. J. Francl, J. M. Krupinsky, and M. P. McMullen, eds. North Dakota Agricultural Experiment Station, Fargo.

15. Elias, E., Cantrell, R. G., and Hosford, R. M., Jr. 1989. Heritability of resistance to tan spot in durum wheat and its association with other agronomic traits. Crop Sci. 29:299-304.

16. Faris, J. D. 1996. RFLP mapping of tan spot resistance genes in wheat. M.S. thesis. North Dakota State University, Fargo.

17. Faris, J. D., Anderson, J. A., Francl, L. J., and Jordahl, J. G. 1996. Chromosomal location of a gene conditioning insensitivity in wheat to a necrosis-inducing culture filtrate from Pyrenophora tritici-repentis. Phytopathology 86:459-463.

18. Fuchs, R. 1991. MacPattern: Protein pattern searching on the Apple Macintosh. Comput. Appl. Biosci. 7:105-106.

19. Fuchs, R. 1994. Predicting protein function: A versatile tool for the Apple Macintosh. Comput. Appl. Biosci. 10:171-178.

20. Gill, S. C., and von Hippel, P. H. 1989. Calculation of protein extinction coefficients from amino acid sequence data. Anal. Biochem. 182:319326.

21. Hosford, R. M., Jr. 1982. Tan spot-Developing knowledge 1902-1981. Pages 1-5 in: Tan Spot of Wheat and Related Disease Workshop. R. M. Hosford, Jr., ed. North Dakota State University, Fargo.

22. Jenzano, J. W., Hogan, S. L., Noyes, C. M., Featherstone, G. L., and Lundblad, R. L. 1986. Comparison of five techniques for the determination of protein content in mixed human saliva. Anal. Biochem. 159:370376.

23. Kawai, M., Rich, D. H., Walton, J. D. 1983. The structure and conformation of HC-toxin. Biochem. Biophys. Res. Commun. 111:398-403.

24. Kishimoto, A., Nishiyama, K., Nakanishi, H., Uratsuji, Y., Nomura, H., Takeyama, Y., and Nishizuka, Y. 1985. Studies on the phosphorylation of myelin basic protein by protein kinase $C$ and adenosine $3^{\prime}: 5^{\prime}$-monophosphate-dependent protein kinase. J. Biol. Chem. 260:12492-12499.

25. Kono, Y., Kinoshita, T., Takeuchi, S., and Daly, J. M. 1989. Structure of amino acids isolated from hydrolyzed $\mathrm{HV}$-toxin $\mathrm{M}$, a host-specific toxinrelated compound produced by Helminthosporium victoriae. Agric. Biol. Chem. 53:505-511.

26. Kungsuwan, A., Noguchi, T., Matsunaga, S., Watanabe, M. F., Watabe, S., and Hashimoto, K. 1988. Properties of two toxins isolated from the blue-green alga Microcystis aeruginosa. Toxicon 26:119-125.

27. Lamari, L., and Bernier, C. C. 1989. Evaluation of wheat lines and cultivars to tan spot (Pyrenophora tritici-repentis) based on lesion type. Can. J. Plant Pathol. 11:49-56.

28. Lamari, L., and Bernier, C. C. 1989. Virulence of isolates of Pyrenophora tritici-repentis on 11 wheat cultivars and cytology of the differential host reactions. Can. J. Plant Pathol. 11:284-290.

29. Lamari, L., and Bernier, C. C. 1991. Genetics of tan necrosis and extensive chlorosis in tan spot of wheat caused by Pyrenophora tritici-repentis. Phytopathology 81:1092-1095.

30. Lee, T. S., and Gough, F. J. 1984. Inheritance of Septoria leaf blotch ( $S$. tritici) and Pyrenophora tan spot (P. tritici-repentis) resistance in Triticum aestivum cv. Carifen 12. Plant Dis. 68:848-851.

31. Lin, B. Z., Meinhardt, S. W., and Francl, L. J. 1993. An alternative method for the isolation of the necrosis toxin of Pyrenophora triticirepentis. (Abstr.) Phytopathology 83:885.

32. McMullen, M. P., and Nelson, D. R. 1992. Tan spot and five years of

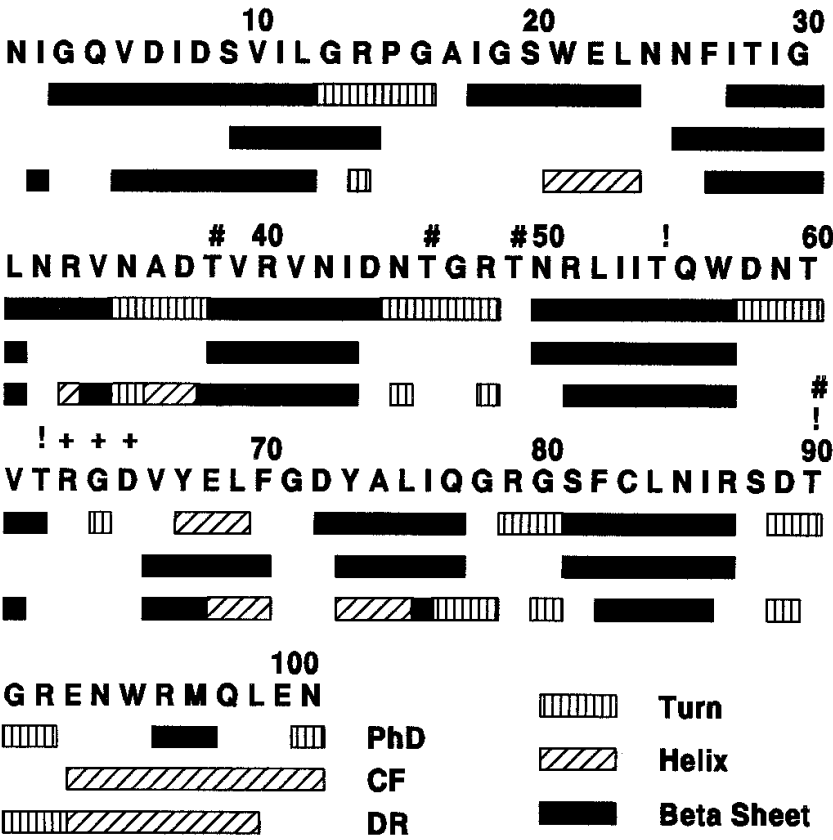

Fig. 6. The secondary structure of the Pyrenophora tritici-repentis Ptr necrosis toxin was predicted by the methods of Chou and Fasman (CF), Deleage and Roux (DR), and Rost and Sander (PHD). Unmarked regions indicate other structure. The following symbols indicate possible phosphorylation sites for protein kinase C (\#), casein kinase II (!), and the possible cell adhesion tripeptide $(+)$. The symbol $\mathrm{X}$ represents either an arginine or aspartate residue.

wheat disease survey. Pages 80-85 in: Advances in Tan Spot Research: Proceedings of the Second International Tan Spot Workshop. L. J. Francl, J. M. Krupinsky, and M. P. McMullen, eds. North Dakota Agricultural Experiment Station, Fargo.

33. Mehta, Y. R., and Gaudêncio, C. A. 1991. The effects of tillage practices and crop rotation on the epidemiology of some major wheat disease. Pages 266-283 in: Wheat for the Nontraditional, Warm Areas. D. F. Saunders, ed. CIMMYT, Mexico D.F., Mexico.

34. Mehta, Y. R., Riede, C. R., Campos, L. A. C., and Kohli, M. M. 1992. Integrated management of major wheat diseases in Brazil: An example for the Southern Cone region of Latin America. Crop Prot. 11:517-524.

35. Nagle, B. J., Frohberg, R. C., and Hosford, R. M., Jr. 1982. Inheritance of resistance to tan spot of wheat. Pages 40-45 in: Tan Spot and Related Disease Workshop. R. M. Hosford, ed. North Dakota State University, Fargo.

36. Pinna, L. A. 1990. Casein kinase 2: An 'eminence grise' in cellular regulation. Biochim. Biophys. Acta 1054:267-284.

37. Rees, R. G., and Platz, G. J. 1983. Effects of yellow spot on wheat: Comparison of epidemics at different stages of crop development. Aust. J. Agric. Res. 34:39-46.

38. Rost, B., and Sander, C. 1993. Prediction of protein structure at better than 70\% accuracy. J. Mol. Biol. 232:584-599.

39. Rost, B., and Sander, C. 1993. Improved prediction of protein secondary structure by use of sequence profiles and neural networks. Proc. Natl. Acad. Sci. U.S.A. 90:7558-7562.

40. Rost, B., and Sander, C. 1994. Combining evolutionary information and neural networks to predict protein secondary structure. Proteins 19:5572 .

41. Rost, B., Sander, C., and Schneider, R. 1994. PHD-An automatic mail server for protein secondary structure prediction. Comput. Appl. Biosci. 10:53-60.

42. Ruoslahti, E., and Pierschbacher, M. D. 1986. Arg-Gly-Asp: A versatile cell recognition signal. Cell 44:517-518.

43. Schägger, H., and von Jagow, G. 1987. Tricine-sodium dodecyl sulfate polyacrylamide gel electrophoresis for the separation of proteins in the range from 1 to $100 \mathrm{kDa}$. Anal. Biochem. 166:368-379.

44. Sreerama, N., and Woody, R. W. 1993. A self-consistent method for the analysis of protein secondary structure from circular dichroism. Anal. Biochem. 209:32-44.

45. Sykes, E. E., and Bernier, C. C. 1991. Qualitative inheritance of tan spot resistance in hexaploid, tetraploid and diploid wheat. Can. J. Plant Pathol. 13:38-44

46. Tomás, A., and Bockus, W. W. 1987. Cultivar-specific toxicity of culture 
filtrates of Pyrenophora tritici-repentis. Phytopathology 77:1337-1340.

47. Tomás, A., Feng, G. H., Reeck, G. R., Bockus, W. W., and Leach, J. E. 1990. Purification of a cultivar-specific toxin from Pyrenophora triticirepentis, causal agent of tan spot in wheat. Mol. Plant-Microbe Interact. 3:221-224.

48. Toumadje, A., Alcorn, S. W., and Johnson, W. C., Jr. 1992. Extending CD spectra of proteins to $168 \mathrm{~nm}$ improves the analysis for secondary structures. Anal. Biochem. 200:321-331.

49. Tuori, R. P., Wolpert, T. J., and Ciufetti, L. M. 1995. Purification and immunological characterization of toxic components from cultures of Pyrenophora tritici-repentis. Mol. Plant-Microbe Interact. 8:41-48.

50. Walton, J. D., Earle, E. D., Stahelin, H., Grieder, A., Hirota, A., and Suzuki, A. 1985. Reciprocal biological activities of the cyclic tetrapeptides chlamydocin and HC-toxin. Experientia 41:348-350.

51. Woodgett, J. R., Gould, K. L., and Hunter, T. 1986. Substrate specificity of protein kinase C. Use of synthetic peptides corresponding to physiological sites as probes for substrate recognition requirements. Eur. J. Biochem. 161:177-184. 